\section{Greit om psykiatri, men ingen orienterende oversikt}

Levander S, Adler H, Gefvert $\mathrm{O}$ et al. Psykiatri

En orienterande översikt. 2. utg. 381 s, tab, ill. Lund: Studentlitteratur, 2008. Pris SEK 502 ISBN 978-91-44-05017-1

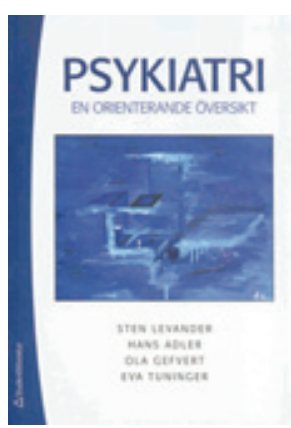

Forfatterne har ambisjoner om at denne oversikten skal kunne brukes i den medisinske grunnutdanningen og også i mange andre utdanningssammenhenger for å bidra til et kunnskapsbasert «samsyn», som det heter. Videre anføres det $\mathrm{i}$ innledningen at sammenliknet med andre lærebøker legges det vekt på mer alvorlige psykiske forstyrrelser, særlig slike som er forbundet med sosiale avvik.

Psykiatri er delikat, har pent utformet layout og er lettlest.

Etter innledende kapitler, der det bl.a. gjøres rede for distinksjonene mellom symptom, episode, syndrom og sykdom og forfatternes biopsykososiale ståsted, tar de for seg de ulike syndromgruppene. I tillegg er det kapitler om intelligens, basal og klinisk psykofarmakologi, utviklingsforstyrrelser, aggresjon og risikovurderinger, noe som ifølge forfatterne ikke er vanlig i denne typen lærebøker. Her har denne sin styrke. Det hele avsluttes så med diverse kapitler vedrørende svensk rettspsykiatri og psykiatrilovgivning for øvrig.

Vedrørende de enkelte syndromene vektlegges psykopatologi- og symptombeskrivelsene. Spesielt i schizofrenikapitlet gir dette et skjevt bilde, særlig siden kapitteloverskriften angir at det handler om vår viktigste folkesykdom. En rekke sentrale temaer er utelatt. Psykofarmakologisk behandling omtales $i$ et eget kapittel, men for øvrig er det lite om behandling og rehabilitering. Tidlig intervensjon er ikke nevnt og diskutert, heller ikke familietilnærming, som f.eks. psykoedukasjon. Det harmonerer ikke med ambisjonene om å gi en orienterende oversikt. Kapitlet om affektive lidelser er også veldig mangelfullt. Det er bare på seks sider, mens f.eks. avsnittene om aggressivitet og seksuelle forstyrrelser er på ti sider hver. Klinisk viktige fenomener som affektive episoder i blandet fase og raske svingninger er ikke nevnt. Rent generelt er det for dårlig dekning av epidemiologi og forebyggende psykiatri. Kriseog katastrofepsykiatri er ikke omtalt. Brukerperspektivet er ikke trukket inn. Svært få av den senere tids interessante funn innen genetikk og nevrobiologi omtales.

Slike forhold gjør at Psykiatri vanskelig kan anbefales som orienterende oversikt over faget. Til det er fremstillingen for skjev. Kanskje forfatterne burde ta steget ut og lage en bok om de deler av faget de behersker best.

\section{Terje Øiesvold}

Salten psykiatriske senter

Nordlandssykehuset

Bodø

\section{God innføringsbok fra «en annen verden»}

Halvorsen K

\section{Å forske på samfunnet}

En innføring i samfunnsvitenskapelig metode. 316 s, tab, ill. Oslo: Cappelen Akademisk, 2007. Pris NOK 458

ISBN 978-82-02-28194-6

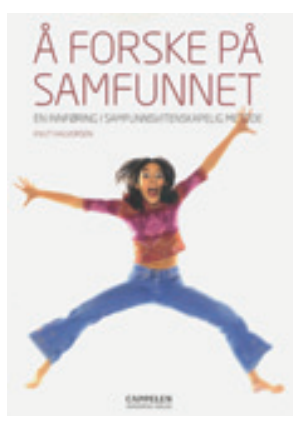

Dette er femte utgave av en innføringsbok som første gang kom ut for mer enn 20 år siden. Det er en hengiven veileder som etter mange år har funnet tilbake til studentundervisningen og $\mathrm{i}$ forordet skriver at studenter først og fremst trenger «praktiske og konkrete råd om hvordan en skal gjennomføre et prosjekt og skrive hva en har funnet ut». Dette gjennomsyrer teksten, som er lettlest og støttes av en delikat utforming. Det er 11 kapitler, og man følger samme opplegg som i tilsvarende utgivelser - en kort, teoretisk innføring og deretter en strukturert, kortfattet og konkret gjennomgang av hele forskningsprosessen. Alt fra spørsmåls- og hypoteseformulering, operasjonalisering av problemet via innhenting og analyse av data, presentasjon av resultatene og fortolk- ningen av dem til den endelige rapportskriving og formidling omtales.

På den positive siden vil jeg trekke frem at forfatteren tar for seg forskning som en generisk aktivitet, med vekt på hvilke grunnleggende metoder som er tilgjengelige og som man kan velge blant når man støter på ulike typer problemer.

Det er balanse i fremstillingen av kvantitative og kvalitative tilnærminger, der bl.a. fenomenet «metodetriangulering» er beskrevet på en kortfattet, men troverdig måte. Det er godt å ha in mente at den ene tilnærmingen er like «verdifull» som den andre. Innenfor medisinen er det mange problemstillinger der en kvalitativ metode ville vært mest hensiktsmessig og følgelig burde vært valgt.

Den pedagogiske kvaliteten høynes betraktelig ved at hvert kapittel avrundes med to-tre spørsmål til diskusjon og en ramme med «Hva har du lært i dette kapitlet?». En knapp håndfull henvisninger til litteratur for videre lesning kommer i tillegg til den omfattende litteraturoversikten bakerst.

Vedleggene består av et innsiktsfullt kapittel om litteratursøking, en oversikt over nyttige nettsteder som jeg ikke husker å ha sett andre steder, ordforklaringer og utfyllende noter det er henvist til i teksten. Under bokstaven d i et godt stikkordregister finner man bl.a. dette: data, databank, datainnsamling, datakilde, datamatrise, Datatilsynet, datum og dataanalyse. Dette innga tillit.

I hvert kapittel dukker det opp flere små ordtak. Blant annet er følgende tillagt Albert Einstein: «Ikke alt som teller kan telles, og ikke alt som kan telles teller.» Videre skal musikeren Count Basie ha sagt: «Det er ikke mangel på tid, bare på tidsfrister.» I Jan Erik Kristiansens Tall kan temmes! har forfatteren funnet at tolking av kvantitative data er «å sette ord på tallene».

På den motsatte siden må det bemerkes at mange dataanalyser, for eksempel av vanlige $2 \times 2$-tabeller, foretas på en uvant og fremmed måte for den som har erfaring i medisinsk statistikk. Men dette bedrer seg når forfatteren kommer over på multivariate analyser og bl.a. illustrerer dette med datautskrifter fra programpakken SPSS.

Avslutningskapitlet om samfunnsforskningens etiske og juridiske aspekter virker naivt og overfladisk for alle som de siste par årene har fulgt situasjonen innen medisinsk forskning.

Under omtalen av Den nasjonale forsk- 